Egyptian Journal of Aquatic Biology \& Fisheries

Zoology Department, Faculty of Science,

Ain Shams University, Cairo, Egypt.

ISSN $1110-6131$

Vol. 25(1): 783 - 794 (2021)

www.ejabf.journals.ekb.eg

\title{
Assessing the effect of hook style on size selectivity and catch rate of the European eel Anguilla anguilla in Bardawil Lagoon, Eastern Mediterranean, Egypt
}

Sahar F. Mehanna ${ }^{1 *}$, Gaber D. Hassanen ${ }^{2}$, Mohamed S. Ahmed ${ }^{3}$, Ola A. Mohamed ${ }^{2}$

${ }^{1}$ Fish Population dynamics Lab, National Institute of Oceanography and Fisheries, Egypt

${ }^{2}$ Faculty of Environmental Agricultural Sciences, Department of Fish Resources and Aquaculture,

Arish University, Egypt

${ }^{2}$ Faculty of Aquaculture and Marine Fisheries, Arish University, Egypt

"Corresponding Author: sahar_mehanna@yahoo.com

\begin{abstract}
ARTICLE INFO
Article History:

Received: Jan. 30, 2021

Accepted: Feb. 19, 2021

Online: Feb. 22, 2021

Keywords:

Bardawil lagoon,

hook style,

catch rate,

European eel,

J-style,

C-style,

management

ABSTRACT

While the landings in coastal waters have not been high in recent years, the European eel is treasured in Egypt for its high sale value (its price averaged 200 LE per kg in 2019-2020). The size selectivity and catch rate of European eel, Anguilla anguilla using small hooks were studied in Bardawil lagoon using two hook styles, J- style and C- style. Catch size, catch rates, and selectivity were monitored during 24 sets in the commercial longline fishery operating in Bardawil lagoon where circle (size 2/0, 3/0 and 4/0) and J-style (size 13) hooks were deployed. The targeted European eel was fished during three months October, November and December during 2019 and 2020. A considerable amount of undersized eel was caught as bycatch by both styles but in more quantities by J-style. Catch rates for European eel were significantly $(\mathrm{P}<0.05)$ higher for circle hooks. This study in Bardawil lagoon longline fisheries indicates that a change in terminal gear from J-style hooks to circle hooks may reduce bycatch mortality. The catch rate (number of fish per 100 hooks) was significantly lower for the J-style hooks. The capture of illegally sized or immature eels was very high in J-style hooks. The estimated Lc (the fish length corresponding to a 50\% chance of capture) indicated that the C-style size $3 / 0$ is the best hook design to catch European eels.
\end{abstract}

\section{INTRODUCTION}

The European eel Anguilla anguilla (L.) is distributed and exploited in fresh, brackish and coastal waters in almost all of Europe and along the Mediterranean coasts of Africa and Asia (Moriarty and Dekker 1997). European eel is a commercially and recreationally important fishery target species. In the last decades, the eel has experienced dramatic stock declines and has been listed as critically endangered. To reduce fishing mortality, several European countries have closed the fishery or introduced stricter management measures which increase the likelihood of catch-and-release in the recreational fishery (Weltersbach et al., 2016). 
The declining of European eel documented on the Atlantic Ocean in recent decades (Dekker et al., 2003; Knights, 2003; Baltazar-Soares et al., 2013; Aalto et al., 2016) was may be related to changes in ocean conditions affecting the survival of leptocephali (the transparent leaf-like larvae) that are born in the Sargasso Sea (Schmidt, 1923). This decline may also be related to reductions in the size of the spawning population of the species (Dekker, 2003\&2004), driven by anthropogenic factors such as habitat loss, pollution, parasite introductions, and overfishing (Haro et al., 2000; Feunteun, 2002).

The fishing mortality on bycatch species resulting from longline fishing may be reduced by decreasing interaction rates or decreasing the mortality of fish at the time of haulback. Recent attention has been given to circle hooks (a hook with the point turned perpendicularly back to the shank) as a means to reduce fisheries mortality. In contrast to J-style hooks, circle hooks tend to slide over soft tissue and rotate as the eye of the hook exits the mouth, frequently resulting in the hook catching in the jaw (Cooke and Suski, 2004). In the longline fishery, a higher proportion of fishes caught in the mouth or jaw should result in less physical damage to the fish and probably higher rates of survival at haulback and after release for bycatch species.

In Bardawil lagoon, the European eel is targeted by the longline fishery especially J-style hooks size 13. This longline fishery operates mainly in the lagoon between October and December. The number of hook deployed is 300 hooks per set and the soaking time from sunset to just before sunrise (less than $10 \mathrm{~h}$ ) (Salem, 2018; Mehanna et al., 2020; Aabed, 2020; Mehanna et al., 2021). This hook style and size had its dangerous impact on the eel size selectivity and mortality.

Because the effective fishery management requires a good knowledge on fishing gears, the present work was done to evaluate the impact of hook style and size on size selectivity and catch rate of European eel in Bardawil lagoon, Eastern Mediterranean, Egypt.

\section{MATERIALS AND METHODS}

\section{Study area}

Bardawil lagoon (Fig. 1) is one of the northern lakes in Egypt and it is a part of the Mediterranean coastal lands of Sinai. It is an important source of local and economic fishes in North Sinai, and it plays an essential role in the fish production in Egypt, where it produces very economically important species of fishes such as seabass, seabream, sole, grey mullet, eel, meager and white grouper. Bardawil lagoon is a shallow hypersaline lagoon, with total area of about $685 \mathrm{~km}^{2}$ extends for a distance of about 95 $\mathrm{km}$, from a point $45 \mathrm{~km}$ east of Port Said and extending to a point $18 \mathrm{~km}$ west of ElArish. Its maximum width is $22 \mathrm{~km}$ and The average depth is $135 \mathrm{~cm}$ with a maximum depth next to Boughaz I and II. A long sand-bar, 200-1000 m wide maximum, separates the lagoon from the adjacent Mediterranean. (Mehanna, 2006; Mehanna and Khalil, 2006; Mehanna, 2013; Salman, 2014; Farouk, 2014). 


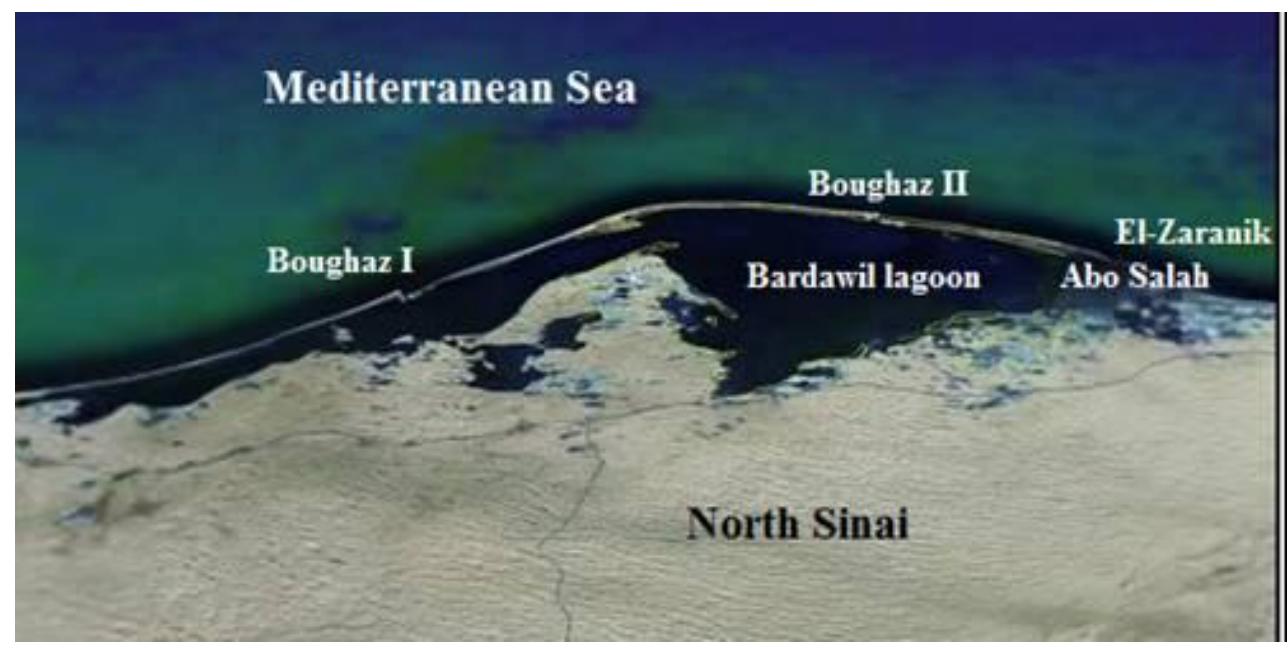

Fig. 1. Bardawill lagoon

\section{Experimental procedures}

Two hook styles were applied in this study, J-style that commonly used by fishermen and the circle style that many studies recommended it. After consulting local longline fishermen, we decided to use two common hook types in the experimental trials: the strong J-style hooks (Fig. 2) (No. 13 with a bend width of $9.9 \mathrm{~mm}$, total length 23.6 $\mathrm{mm}$ ) and three different sizes of weak C- style hooks size no. 3/0 (with a bend width of $9.9 \mathrm{~mm}$ ), 4/0 (with a bend width of $7.1 \mathrm{~mm}$ ) and $2 / 0$ (with a bend width of $11 \mathrm{~mm}$ ) as shown in figure 3 . The longlines used in this study consisted of monofilament mainline $60 \mathrm{~mm}$ and $30 \mathrm{~mm}$ leaders. The space between leaders was approximately $3 \mathrm{~m}$. Each longline consisted of 100 hooks. Four long-line selectivity trials have been carried out twice monthly during two fishing seasons (2019 and 2020) from October to December.

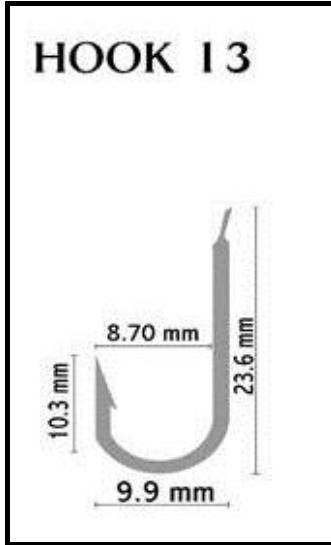

Fig. 2. J style hooks of size 13 


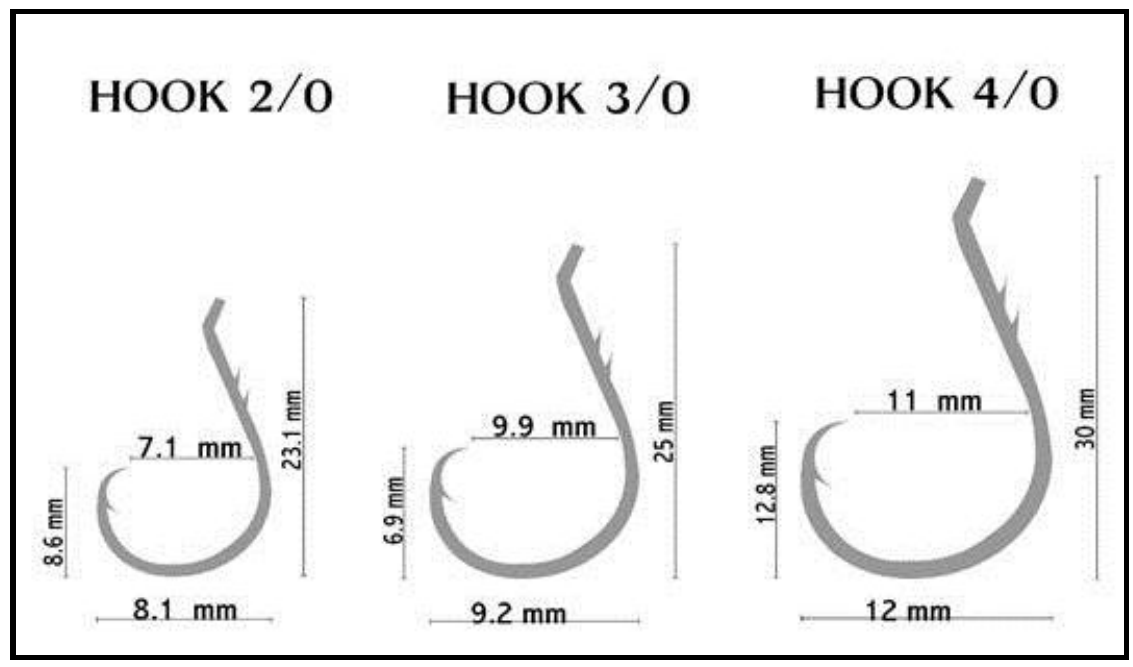

Fig. 3. C style hooks of different sizes

Four baskets were prepared each of 350 hooks; one for each C-style hook size and one for J-style hook size 13. The baskets were deployed twice a month for three months (fishing season of line fishery) from October to December, 2019 and repeated in 2020. Line setting was started in the evening and completed before sunset and the hauling began at dawn and took 7-9 $\mathrm{h}$ which is the usual style of commercial shallow set longline fishing boats working in the lagoon. Samples were taken directly to the laboratory. The catch data of the European eel were analyzed and the catch rate was analyzed and compared between the two hook styles used.

\section{Biological measurements}

Length measurements of European eel specimens were taken for total body length to nearest millimeter and sorted afterwards in sequential length groups of one centimeter interval. Eel were classified into two groups: target (adult, $\geq 46 \mathrm{~cm} \mathrm{TL}$ ) and undersized (juvenile $\leq 45 \mathrm{~cm}$ TL) to examine differences in catch rates by hook style.

\section{Size selectivity and Length at first capture $\left(L_{c}\right)$}

Logistic selectivity curves were constructed using the general SELECT model (Millar, 1992), after Erzini and Castro (1998), who employed the methodology proposed by Kirkwood and Walker (1986) and Wulff (1986):

$$
\mathrm{Si}, \mathrm{j}=1 / 1+\mathrm{e}^{-\mathrm{bi}(\mathrm{j}-\mathrm{L} 50 \mathrm{i})}
$$

where $\mathrm{Si}, \mathrm{j}$ is selectivity for hook size $\mathrm{i}$ and size class $\mathrm{j}, \mathrm{b}_{\mathrm{i}}$ is the slope of the selectivity curve, $\mathrm{l}_{\mathrm{j}}$ is the size class $\mathrm{j}$ and $\mathrm{L}_{50 \mathrm{i}}$ is the length at $50 \%$ selection for hook size $\mathrm{i}$.

\section{RESULTS AND DISCUSSION}

A growing interest in catch-and-release recreational angling has lead to gear developments intended to reduce injury and mortality of fish that are released (Muoneke and Childress, 1994). Circle hooks have gained a due care in recent years for their apparent conservation benefits relative to conventional J-style hooks (e.g. Montrey, 1999), and the use of circle hooks is now encouraged by outdoor media, tackle 
manufacturers, resource management agencies, and conservation organizations. In addition, circle hooks are legislatively mandated for some specialized fisheries. In this study we compared between the J-style and C-style hooks selectivity and determine the most appropriate style to catch European eel in Bardawil lagoon.

\section{Line fishery description}

The lines methods including the trolling hand line and long line has become widely used for catching seabass, grouper, meagre and recently European eel in Bardawil lagoon. The principle is to use baited hooks on lines. For longline in Bardawil lagoon, the mainline is of 300 to $450 \mathrm{~m}$ length to which 250 to 300 branch lines are attached. Each branch line has a hook of about 2 to $5 \mathrm{~cm}$ length and about 0.8 to $1.5 \mathrm{~cm}$ width. The baits used in this method are small shrimps and grey mullets and the main catch is eels and groupers. In the hand-line, hooks are used individually to catch single fish, while light is used to attract fishes. This method of fishing is operated only to catch the nocturnal fishes and its main catch is Dicentrarchus labrax and D. punctatus. The boats are used the two long and hand line techniques, where each boat has one to three fishermen (Mehanna et al., 2021).

\section{Number, size and yield of fish caught}

During the fishing trips, 1215 European eel, Anguilla anguilla, were caught by various hook treatments. In total, 405 fish ranging in size from 25 to $61 \mathrm{~cm}$ (Fig. 4) were caught using the standard J hook style size 13 of which $76 \%$ were undersized ( $\leq 45 \mathrm{~cm}$ TL). The average total length was estimated at $38.4,52.1$ and $41.6 \mathrm{~cm}$ TL for immature, mature and total sample, respectively.

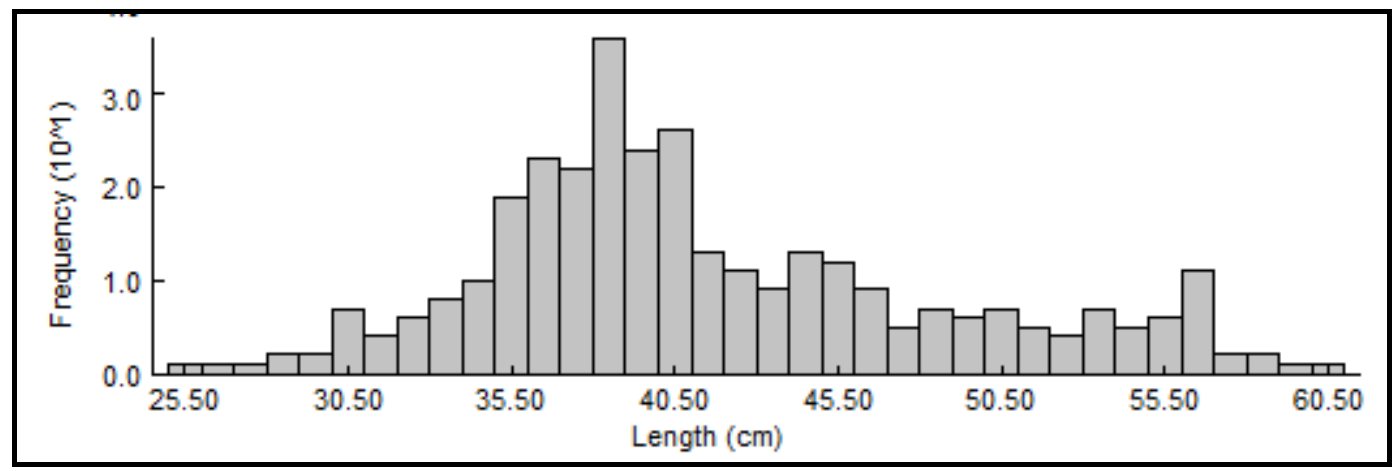

Fig. 4. Length distribution of European eel caught by J-style in Bardawil lagoon

A total of 810 eel were caught with the $C$ hook style; 390, 260 and 160 specimens in hook size 4/0,3/0 and 2/0 respectively. The largest hooks (sizes 4/0) are caught more fish than the smallest ones. With circle hooks, the specific fish sizes caught by the three hook sizes were significantly diff erent. The total eel length ranging from 38-64, 35-87 and 30-59 $\mathrm{cm}$ TL for hooks 4/0, 3/0 and 2/0 respectively (Fig. 5). Also, the percentage of immature eel caught by circle hooks was very small except for hook size $2 / 0$ forming $30 \%, 15 \%$ and $56 \%$ of the total samples by $4 / 0,3 / 0$ and $2 / 0$ respectively. The average total length of the eel caught by different sizes of C-style was estimated at $49.9,59.5$ and $43.9 \mathrm{~cm}$ for $4 / 0,3 / 0$ and 
$2 / 0$ hooks respectively. It is clear that the C-style size 3/0 was the best one among the different hook sizes.
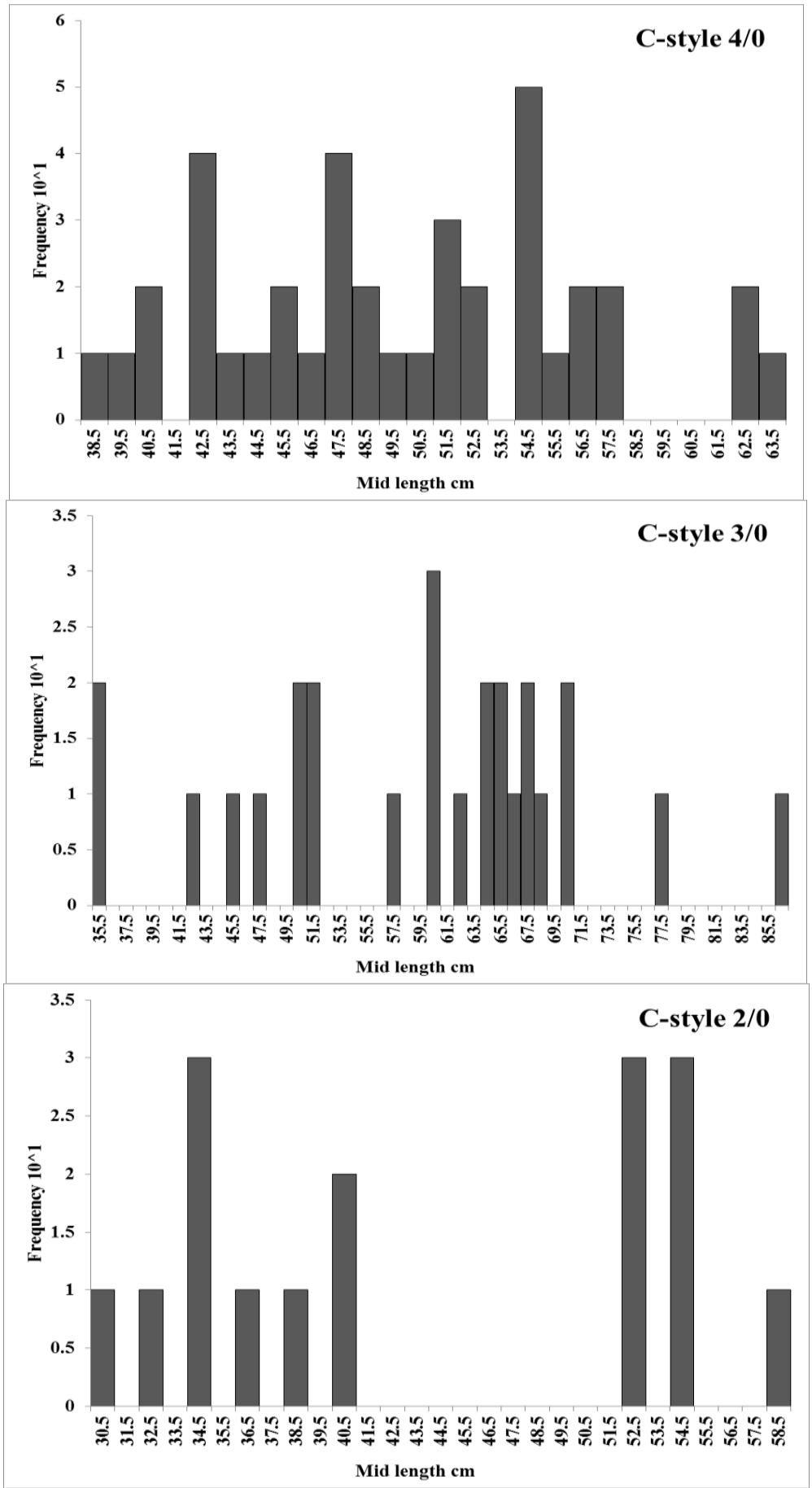

Fig. 5. Length distribution of European eel caught by C-style in Bardawil lagoon

Average eel yield caught with different hooks used in this study was 50.3, 58.1, 97.3 and $45.3 \mathrm{Kg}$ for $\mathrm{J}$ hook size $13, \mathrm{C}$ hook $4 / 0,3 / 0$ and $2 / 0$ respectively. The yield of different hooks styles and sizes were significantly diff erent and the $\mathrm{C}$ style size $3 / 0$ was the best one. 


\section{Size selectivity and catch rate}

After testing all hooks, the best C-style hook was the size 3/0. Slopes and sizes at 50\% selection and the corresponding logistic selectivity curves for the four hook types are given in Fig. 6. The length at first capture of A. anguilla for the J-style hook of size 13 was 39.5 $\mathrm{cm}$, while its value for C-style hooks was $41.3,50.4$ and $38.1 \mathrm{~cm}$ for sizes $4 / 0,3 / 0$ and 2/0 respectively.

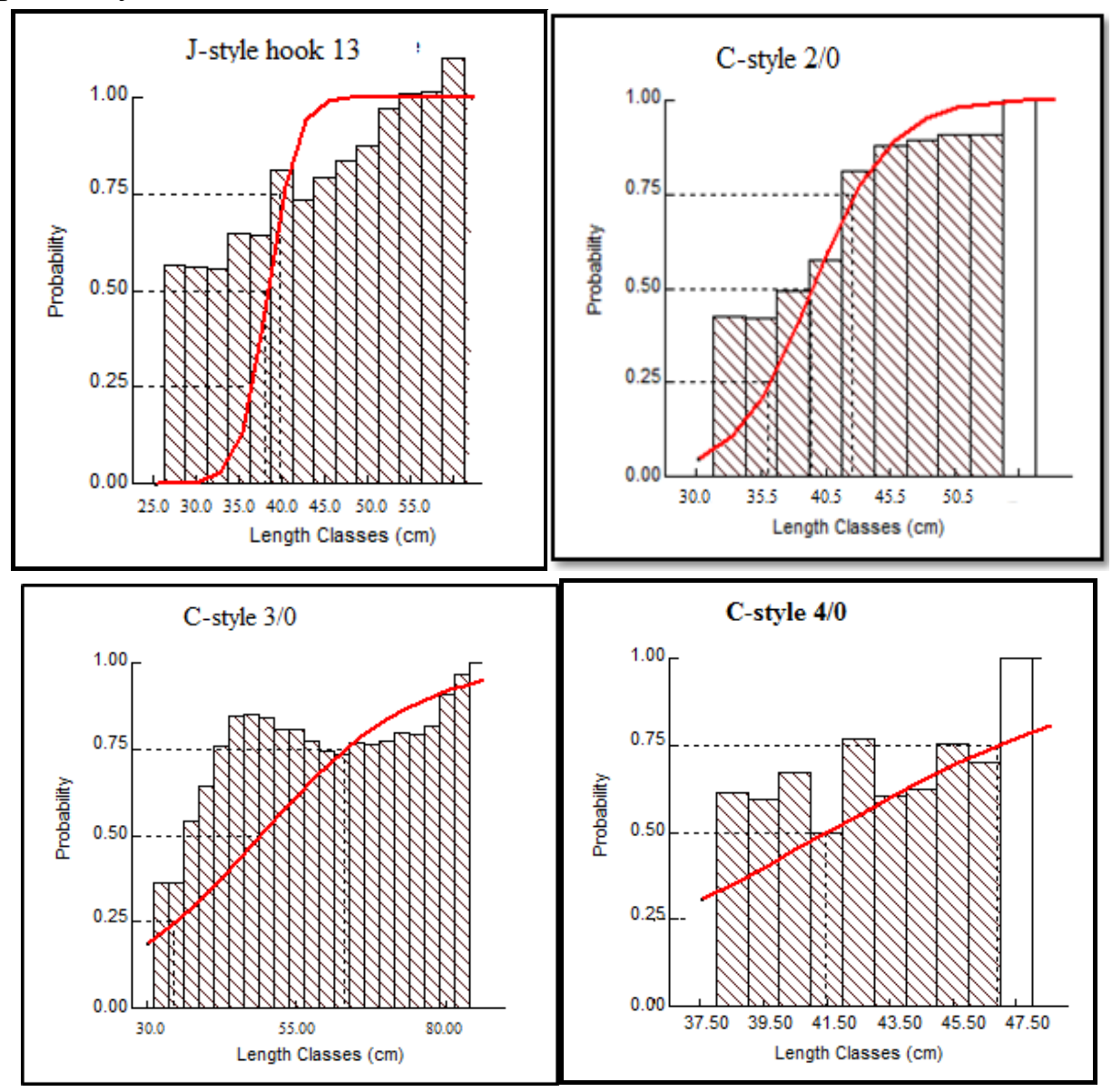

Fig. 6. Selectivity curves of European eel caught by different hooks in Bardawil lagoon

In many selectivity studies on longline fisheries, the catch rates are much higher for small hooks than for large hooks (Erzini et al., 1996, 1998, 1999; Halliday, 2002). In our results, larger hooks were less efficient at catching smaller eel and more efficient at catching larger ones. Also, the yield produced by the diff erent hook sizes showed a fluctuation among hooks types. Finally, we present hook style and size as a good measure for conservation target stocks in our commercial and recreational fishery. The results obtained from this study are a good tool for fisheries managers, ecologists and biologists as it may help in resource conservation in commercial and recreational marine fisheries.

Our results came in accordance with the previous studies that investigated the influence of circle hooks on catch rates and at-haul mortality rates of target and bycatch species to determine their potential as a management tool. Forster (1973) who found that the circle 
hook seems to be more effective than the traditional J-hook for capturing gadoid species and smaller elasmobranchs, but not macruid species and larger elasmobranchs. Nicholson and Jordan (1994) advised by switching to circle hooks to increase retention and decrease bycatch mortality in the Gulf of Mexico. IPHC (1998) stated that the circle hooks have been used for years by commercial fisheries in the U.S. Pacific Northwest and are currently mandatory in the U.S. pelagic longline fishery. Other studies have shown reduced rates of serious injury with circle hooks (e.g, Skomal et al., 2002) and increased rates of post-release survival (Horodysky and Graves, 2005). Falterman and Graves (2002) made a comparison between circle hook and $\mathrm{J}$ hook mortality and hooking efficiency in the pelagic longline industry (CPUEs were higher using circle hooks, both for target fish (yellowfin tuna) and bycatch (15 other species). They found that mortality rates were lower for circle-hookcaptured fish, both for the target and bycatch species. Overall, more than $95 \%$ of circlehooked fish were hooked in the jaw and had lower rates of gut hooking relative to J-hooked fish. Also, circle hooks have been reported to reduce the rate of deep hooking events in tuna, shark, billfishes, and sea turtle species in several pelagic longline fisheries and consequently, circle hooks have been proposed as a conservation measure to reduce mortality for vulnerable bycatch species that have high rates of interaction with longline gear (Falterman and Graves 2002; Cooke and Suski 2004; Kerstetter and Graves 2006; Read, 2007; Rice et al., 2012; Godin et al., 2012; Graves et al., 2012). Burns (2019) said that he encourage tackle manufacturers to continue to develop new hook designs that have the potential to provide conservation benefit to caught and released fish.

\section{CONCLUSION}

In conclusion, catch rates, size selectivity and mortality of bycatch in line fisheries are influenced by a number of variables including hook size and design (Forster, 1973; Anon., 1983; Skeide et al., 1986; Bjordal and Løkkeborg, 1996). In our study we have focused on hook style because of its effect on reducing the bycatch mortality and for minimizing the capture of undersized fish. Our results indicated that circle hooks were more frequently hooked in the jaw, and less frequently hooked in the gut than conventional $\mathrm{J}$ hook types so the $\mathrm{C}$-style is better than the J-style as overall the mortality rates were consistently lower for circle hooks than J-style hooks.

This study is part of $\mathrm{PhD}$ research on the selectivity of line fisheries in Bardawil lagoon for the first time, which will hopefully contribute to the improved management and utilization of commercially important species in the lagoon. As circle hooks have rapidly become popular among commercial and recreational anglers worldwide, based on the assumption that their use helps in the conservation of fisheries resources, we need to make more detailed studies to support these assertions. Government and Fisheries research institution along with different agencies and interested bodies must give a due care to this kind of scientific research to protect the marine ecosystem and commercial fish stocks from overexploitation and destructive fishing gears. 


\section{REFERENCES}

Aabed, M. S. (2020). Assessment of fishing gears used in Bardawil lagoon. MSc. Thesis, Agriculture Fac., Dep. of Animal Production \& Fish resources, Suez Canal Univ.

Aalto, E., Capoccioni, F., Terradez Mas, J., Schiavina, M., Leone, C., De Leo, G., and Ciccotti, E. (2016). Quantifying 60 years of declining European eel (Anguilla anguilla L., 1758) fishery yields in Mediterranean coastal lagoons. ICES Journal of Marine Science, 73: 101-110.

Anon (1983). Circle hooks outfish traditional halibut hooks. Mar. Fish. Rev. 45: 10-12.

Armstrong, D.W.; Ferro, R.S.T.; MacLennan, D.N. and Reeves, S.A. (1990). Gear selectivity and the conservation of fish. J. Fish. Biol., 37A: 261-262.

Baltazar-Soares, M., Biastoch, A., Harrod, C., Hanel, R., Marohn, L., Prigge, E., Evans, D., et al. (2013). Recruitment collapse and population structure of the European Eel shaped by local ocean current dynamics. Current Biology, 24(1): 104-108.

Bjordal, Å. and Løkkeborg, S. (1996). Longlining. Fishing News Books. Oxford: 156 pp.

Burns, A. G. (2019). A Comparison of Circle and J Hook Performance within the Grenadian Pelagic Longline Fishery.Master's thesis. Nova Southeastern University. Retrieved from NSUWorks, (510). https://nsuworks.nova.edu/occ $\underline{\text { stuetd } / 510 .}$

Campos, A.; Fonseca, P.; Erzini, K. (2003). Size selectivity of diamond and square mesh cod ends for four by-catch species captured in the crustacean fishery off the Portuguese south coast. Fish. Res., 60: 79-97.

Casselman, J. M. (2003). Dynamics of resources of the American eel, Anguilla rostrata: declining abundance in the 1990s. In Eel Biology, pp. 255-274 Ed. by K. Aida, K. Tsukamoto, and K. Yamauchi. Springer, Tokyo.

Cooke, S. J. and Suski, C. D. (2004). Are circle hooks and effective tool for conserving marine and freshwater recreational catch-and-release fisheries? Aquat. Conserv.: Mar. Freshw. Ecosyst. 14: 299-326.

Dekker, W. (2003). Did lack of spawners cause the collapse of the European eel, Anguilla anguilla? Fisheries Management and Ecology, 10: 365-376.

Dekker, W. (2004). Synthesis and analyses. In Slipping through our Hands - Population Dynamics of the European Eel, pp. 127-145. PhD thesis, Faculteit der Natutuurweten Schappen, Wiskunde en Informatica, The Netherlands.

Dekker, W., Casselman, J. M., Cairns, D. K., Tsukamoto, K., Jellyman, D., and Lickers, H. (2003). Worldwide decline of eel resources necessitates immediate action: Que bec declaration of concern. Fisheries, 28: 28-30.

Erzini, K. and Castro, M. (1998). An alternative methodology for fitting selectivity curves to pre-defined distributions. Fish. Res., 34: 307- 313.

Erzini, K.; Goncalves, J. M. S.; Bentes, L.; Lino, P. and Cruz, J. (1996). Species and size selectivity in a Portuguese multi species artisanal fishery. ICES J. Mar. Sci., 53: 811-819. 
Erzini, K.; Goncalves, J. M. S.; Bentes, L.; Lino, P. G. and Ribeiro, L. (1998). Species and size selectivity in a red sea bream longline metier in the Algarve (southern Portugal). Aquat. Living Resour., 11: 1-11.

Erzini, K.; Gonçalves, J. M. S.; Bentes, L.; Lino, P. G. and Ribeiro, J. (1999). Catch composition, catch rates and size selectivity of three long-line methods in the Algarve (southern Portugal). Bol. Inst. Esp. Oceanogr., 15 (1-4): 313-323.

Falterman, B. and Graves, J. E. (2002). A preliminary comparison of the relative mortality and hooking efficiency of circle and straight shank ("J") hooks used in the pelagic longline industry. Am. Fish. Soc. Symp., 30: 80-87.

Farouk, A. (2014). Studies on water Quality, pollution by heavy metals in water, Soil \& Fish and stock assessment in Bardawil lagoon. PhD. Thesis, Fac. of Science, AlAzhar University.

Feunteun, E. (2002). Management and restoration of European eel population (Anguilla anguilla): an impossible bargain. Ecological Engineering, 18: 575-591.

Forster, G. R. (1973). Line fishing on the continental slope: the selective effect of different hook patterns. J. Mar. Biol. Ass. UK, 53: 749-751.

Godin, A. C.; Carlson, J. K. and Burgener, V. (2012). The effect of circle hooks on shark catchability and at-vessel mortality rates in longline fisheries. Bulletin of Marine Science, 88(3): 469-483. https://doi.org/10.5343/bms.2011.1054

Graves, J. E.; Horodysky A. Z. and Kerstetter, D. W. (2012). Incorporating circle hooks into Atlantic pelagic fisheries: case studies from the commercial tuna/swordfish longline and recreational billfish fisheries. Bulletin of Marine Science, 88: 411422. http://dx.doi.org/10.5343/bms.2011.1067

Hall, M. A. (1996). On bycatches. Rev. Fish Biol. Fish. 6, 319-352.

Kerstetter, D. W. and Graves, J. E. (2006). Effects of circle versus J-hooks on target and non-target species in a pelagic longline fishery. Fish. Res., 80: 239-250.

Haro, A.; Richkus, W.; Whalen, K.; Hoar, A.; Busch, W. D.; Lary, S.; Brush, T. et al. (2000). Population decline of the American eel: implications for research and management. Fisheries, 25: 7-16.

IPHC (International Pacific Halibut Commission) (1998). The Pacific halibut: biology, fishery, and management. IPHC Technical Report 40, Seattle, Washington.

Kerstetter, D. W. and Graves, J. E. (2006). Effects of circle versus J-hooks on target and non-target species in a pelagic longline fishery. Fish. Res., 80: 239-250.

Kirkwood, G. P. and Walker, T. I. (1986). Gill net mesh selectivities for gummy shark, Mustelus Antarcticus Gu“ nther, taken in Southeastern Australian waters. Aust. J. Mar. Freshw. Res., 37: 689-697.

Knights, B. (2003). A review of the possible impacts of long-term oceanic and climate changes and fishing mortality on recruitment of anguillid eels of the Northern Hemisphere. Science of the Total Environment, 310: 237-244 
Mehanna, S. F. (2006). Lake Bardawil fisheries: current status and future sight. J. Egyp. Ger. Soc. Zool., 51(D): 91-105.

Mehanna, S. F. (2013). Sustainable development of Bardawil lagoon fisheries. First Regional Symposium on Sustainable Small-Scale Fisheries 27 - 30 November 2013, St. Julian's Malta.

Mehanna, S. F. (2020). Challenges faced the small scale fisheries and its sustainable development. ICAR- Central Marine Fisheries Research Institute, Research Centre Mangalore, 7-10 January 2020.

Mehanna, S. F.; Eid, A. M.; Ali, B. A. and Aabed, M. S. (2020). Fishing gears, catch composition and length at first capture of the common fish species in Bardawil lagoon, Egypt. Egyptian J. of Aquat. Biol. \& Fisheries, 24(5): 523 - 538.

Mehanna, S. F.; Hassanen, G. D.; Ahmed, M. S. and Mohamed, O. A. (2021). The effect of hook size on size selectivity in Bardawil lagoon artisanal longline fishery, eastern Mediterranean, Egypt. Egyptian J. Aquat. Biol. \& Fisheries, 25 (in press).

Mehanna, S. F. and Khalil, M. T. (2006). Lake Bardawil fisheries: in Lake Bardawil: Zaranik Protected Area, Khalil, M.T. and Shaltut, K. (eds). Publication of National Biodiversity Unit No. 15, Egyptian Environmental Affairs Agency (EEAA), Cairo, 599 pp.

Millar, R. B. (1992). Estimating the size-selectivity of fishing gear by conditioning on the total catch. J. Am. Stat. Assoc., 87: 962-968.

Millar, R. B. and Fryer, R. J. (1999). Estimating the size-selection curves of towed gears, traps, nets and hooks. Rev. Fish Biol. Fish., 9 (1): 89-116.

Moreno, S.; Pol, J. and González, C. (1992). Selection properties of the baited hooks used in the Cuban long-line fishery of Campeche bank, Gulf of Mexico. Naga, The ICLARM Quarterly, 15: 28-29.

Moriarty C. and Dekker W. (eds.) (1997). Management of the European Eel. Fisheries Bulletin (Dublin), 15: $110 \mathrm{pp}$.

Nicholson, N. and Jordan, S. R. (1994). Biotelemetry study of red drum in Georgia, November 1989-June 1993. Georgia Department of Natural Resources, Coastal Resources Division. Brunswick, GA.

Read, A. (2007). Do circle hooks reduce the mortality of sea turtles in pelagic longlines? A review of recent experiments. Biol. Cons., 135: 155-169.

Rice, P. H.; Serafy, J. E.; Snodgrass, D. and Prince, E. D. (2012). Performance of nonoffset and 10 offset 18/0 circle hooks in the United States pelagic longline fishery. Bulletin of Marine Science, 88(3): 571-587. https://doi.org/doi/10.5343/bms. 2011.1095

Salem, M. (2018). Preliminary assessment and mitigating by-catch of European eel in a longline fishery in Bardawill lagoon, north Sinai, Egypt. Egyptian J. Anim. Prod., 55(3): 187-194. 
Salman, S. (2014). Fisheries characteristics and population dynamics of commercial species of family Soleidae at Bardawil Lagoon, North Sinai, Egypt. MSc. Thesis, Suez Canal University.

Schmidt, J. (1923). The breeding places of the eel. Philosophical Transactions of the Royal Society, 211: 179-208

Skeide, R.; Bjordal, A. and Løkkeborg, S. (1986). Testing of a new hook design (E-ZBaiter) through comparative longline fishing trials. ICES C.M. 1986/B: 25.

Skomal, G. B.; Chase, B. C. and Prince, E. D. (2002). A comparison of circle hook and straight hook performance in recreational fisheries for juvenile Atlantic bluefin tuna. Am. Fish. Soc. Symp., 30: 57-65.

Weltersbach, M. S.; Ferter, K.; Sambraus, F. and Strehlow, H. V. (2016). Hook shedding and post-release fate of deep-hooked European eel. Biol. Conserv., 199: 16-24.

Wulff, A. (1986). Mathematical model for selectivity of gill nets. Archiv fur Fischereiwissenschaft, 37: 101-106. 